\title{
PROPOSAL FOR AN INDEX TO CLASSIFY IRRIGATION WATER QUALITY: A CASE STUDY IN NORTHEASTERN BRAZIL ${ }^{(1)}$
}

\author{
Celsemy Eleutério Maia ${ }^{(2)} \&$ Kelly Kaliane Rego da Paz Rodrigues ${ }^{(3)}$
}

\begin{abstract}
SUMMARY
One way of classifying water quality is by means of indices, in which a series of parameters analyzed are joined a single value, facilitating the interpretation of extensive lists of variables or indicators, underlying the classification of water quality. The objective of this study was to develop a statistically based index to classify water according to the Irrigation Water Quality Index (IWQI), to evaluate the ionic composition of water for use in irrigation and classify it by its source. For this purpose, the database generated during the Technology Generation and Adaptation (GAT) program was used, in which, as of 1988, water samples were collected monthly from water sources in the states of Paraíba, Rio Grande do Norte and Ceará. To evaluate water quality, the electrical conductivity (EC) of irrigation water was taken as a reference, with values corresponding to $0.7 \mathrm{dS} \mathrm{m}^{-1}$. The chemical variables used in this study were: $\mathrm{pH}, \mathrm{EC}, \mathrm{Ca}, \mathrm{Mg}, \mathrm{Na}, \mathrm{K}, \mathrm{Cl}, \mathrm{HCO}_{3}$, $\mathrm{CO}_{3}$, and $\mathrm{SO}_{4}$. The data of all characteristics evaluated were standardized and data normality was confirmed by Lilliefors test. Then the irrigation water quality index was determined by an equation that relates the standardized value of the variable with the number of characteristics evaluated. Thus, the IWQI was classified based on indices, considering normal distribution. Finally, these indices were subjected to regression analysis. The method proposed for the IWQI allowed a satisfactory classification of the irrigation water quality, being able to estimate it as a function of EC for the three water sources. Variation in the ionic composition was observed among the three sources and within a single source. Although the water quality differed, it was good in most cases, with the classification IWQI II.
\end{abstract}

Index terms: Salinity, electrical conductivity, ionic composition.

(1) Received for publication in August 8, 2011 and approved in March 7, 2012.

(2) Agronomist, Doctor in Natural Resources. Professor of the Environmental and Technological Sciences Department of the Universidade Federal Rural do Semiárido (Rural Federal University of the Semiarid Region) - UFERSA. Fellowship holder from the CNPq. E-mail: celsemy@ufersa.edu.br

(3) Agronomist, Master's degree in Irrigation and Drainage, UFERSA, BR 110, km 47, Costa e Silva, CEP 59625-900 Mossoró (RN). E-mail: kellykaliane@yahoo.com.br 


\title{
RESUMO: PROPOSTA DE UM ÍNDICE PARA CLASSIFICAR ÁGUA PARA IRRIGAÇÃO: UM CASO DA REGIÃO NORDESTE DO BRASIL
}

\begin{abstract}
Uma forma de classificar a qualidade da água é por meio de índices, os quais podem resumir uma série de parâmetros analisados em um único número, o que facilita a interpretação de extensas listas de variáveis ou indicadores, possibilitando classificar a qualidade da água. Com isso, os objetivos deste trabalho foram desenvolver um índice com base estatística para classificar as águas de acordo com o Índice de Qualidade de Água para Irrigação (IQAI), avaliar a composição iônica da água para uso na irrigação e classificá-la por fonte. Para isso, foi utilizado o banco de dados gerado durante o programa Geração e Adaptação de Tecnologia (GAT), no qual, a partir de 1988, foram coletadas mensalmente amostras de água em fontes dos Estados da Paraíba, Rio Grande do Norte e Ceará. Para avaliar a qualidade da água, tomou-se como referência a condutividade elétrica da água de irrigação (CE), cujo valor corresponde a $0,7 \mathrm{dS} \mathrm{m} \mathrm{m}^{-1}$. As variáveis químicas utilizadas neste trabalho foram: $\mathrm{pH}, \mathrm{CE}, \mathrm{Ca}, \mathrm{Mg}, \mathrm{Na}, \mathrm{K}, \mathrm{Cl}, \mathrm{HCO}_{3}, \mathrm{CO}_{3}$ e $\mathrm{SO}_{4}$. Para todas as características avaliadas observou-se a normalidade dos dados pelo teste de Lilliefors. Em seguida, determinou-se o índice de qualidade de água para irrigação por meio de uma equação que relaciona o valor padronizado da variável analisada com o número de características avaliadas. Assim, classificou-se o IQAI a partir de índices, considerando a distribuição normal. Finalmente, esses índices foram submetidos à regressão. O método proposto para o IQAI permitiu classificar satisfatoriamente a qualidade da água para irrigação, podendo estimá-lo em função da CE para as três fontes. Observou-se variação na composição iônica entre as três fontes e em uma mesma fonte. Apesar de terem sido observadas águas de diferentes qualidades, predominaram águas de boa qualidade, com IQAI II.
\end{abstract}

Termos de indexação: salinidade, condutividade elétrica, composição iônica.

\section{INTRODUCTION}

Water quality is understood as the physical, chemical and biological characteristics that influence its suitability for a specific use, in other words, the relationship between the water quality and the user's needs (Ayers \& Westcot, 1991). According to Shalhevet \& Kamburov (1976) irrigation water quality is mainly defined by the total quantity of dissolved salts and its ionic composition depending on the water source, location and time of water sampling. Therefore, water is becoming a growing concern, not only with regard to the quantity available, but mainly in relation to its quality, giving rise to losses and limitations to its multiple uses because, depending on the physical, chemical and biological characteristics, its use may be limited or unviable. Thus the use of water for irrigation, while contributing significantly to increased productivity, may in certain situations, above all in arid and semiarid climate zones, lead to the accumulation of salt contents in the soil, reducing the osmotic potential and soil fertility.

For irrigated agriculture, numerous classifications for water use have been developed, each with a certain suitability, although none has proved entirely satisfactory. Thus, in waters classified with different quality degrees, chemical alterations and induction of salinity in soils may occur at different levels (Maia, 1996). Some classifications are however misleading, since in terms of water composition, they are based exclusively on the balance among cations, synthesized in the Sodium Adsorption Ratio (SAR), while others are based on the dominant proportion of chloride in the anions in solution and some, based on anions, use only bicarbonate (Audry \& Suassuna, 1995). Due to some difficulties in classifying irrigation water quality, some authors have used multivariate techniques (Ganfopadhyay et al., 2001; Singh et al., 2005; Stigter et al., 2006), mainly since these techniques reduce the data amount, allowing an interpretation for each variable in association with other factors, e.g, water source, climate, soil type, and anthropogenic influence.

Thus, any classification schema must take into consideration the effect of irrigation water on plants and soil since, in the field, plants react to water and soil and the soil may be affected by water. It is thus unlikely that one standard classification will be adequate for all conditions and, for that reason, there are various irrigation water classification models, from some rather empirical to the currently most commonly used. One way of classifying 
irrigation water quality is by means of indices that summarize a series of characteristics in a single value, facilitating the interpretation of extensive lists of variables or indicators, underlying the classification of water quality. The irrigation water quality index is an adimensional number generated from the aggregation of certain data by means of specific methods that indicates water quality for diverse purposes.

The objective of this study was to develop a statistically based index to classify waters in northeastern Brazil by the Irrigation Water Quality Index (IWQI) and evaluate the ionic composition of water for irrigation and classify it according to the water source.

\section{MATERIAL AND METHODS}

The data used for this study were derived from a databank generated by a program for generation and implantation of technologies adapted to the conditions of the small farmer (GAT). Water from different sources was sampled for different periods on properties in the states of Ceará (11 months), Paraíba (34 months) and Rio Grande do Norte (19 months) as of the beginning of 1988 (Medeiros, 1992).

The databank, after critical analysis to eliminate outliers, consisted of 537 analyses, originating from 55 rural properties (17 in RN, 19 in $\mathrm{CE}$ and 19 in $\mathrm{PB}$ ). The water samples were chemically analyzed for: $\mathrm{pH}, \mathrm{EC}, \mathrm{Ca}, \mathrm{Mg}, \mathrm{Na}, \mathrm{K}, \mathrm{Cl}, \mathrm{HCO}_{3}, \mathrm{CO}_{3}$, and $\mathrm{SO}_{4}$. The Sodium Adsorption Ratio (SAR) was calculated by $\mathrm{SAR}=\mathrm{Na} /((\mathrm{Ca}+\mathrm{Mg}) / 2)^{0.5}$. To evaluate water quality, reference water samples with electrical conductivity (EC) equal to or less than $0.7 \mathrm{dS} \mathrm{m}^{-1}$ were used (173 samples, of which 85 from the well, 31 from a river and 57 from a dam reservoir). According to Ayers \& Westcot (1991), the samples in this EC range may be used without any restriction degree with regard to salinity. In the reference samples, the mean values and respective standard deviation were calculated for each characteristic evaluated for the three water sources. For all characteristics evaluated, data normality was confirmed by Lilliefors test.

To calculate the deviation from the reference values for each characteristic, considering normal data distribution, the data were standardized according to equation 1 .

$$
z_{i}=\frac{x-\bar{x}}{\sigma}
$$

in which $Z_{i}=$ standardized value of the characteristic analyzed; $x=$ value of the characteristic evaluated at the water source; $\bar{x}=$ mean value of the characteristic evaluated in the reference population; $\sigma=$ standard deviation of the characteristic evaluated in the reference population.

The Quality Index was calculated for each characteristic $\left(\mathrm{WQI}_{\mathrm{i}}\right)$ in the sample, for which $\mathrm{WQI}_{\mathrm{i}}$ was determined for $\mathrm{Ca}, \mathrm{Mg}, \mathrm{Na}, \mathrm{K}, \mathrm{Cl}, \mathrm{HCO}_{3}+\mathrm{CO}_{3}$, $\mathrm{SO}_{4}$, and the SAR (equation 2) and the Irrigation Water Quality Index (IWQI) by equation 3.

$$
\begin{gathered}
W Q I_{i}=\sqrt{z_{i}^{2}} \\
I W Q I=\frac{1}{N} \sum_{i=1}^{N} W Q I_{i}
\end{gathered}
$$

in which $\mathrm{WQI}_{\mathrm{i}}=$ Water Quality Index for the characteristic; IWQI = Irrigation Water Quality Index; $Z_{i}=$ standardized value of the variable; $N=$ number of characteristics evaluated.

For $\mathrm{WQI}_{\mathrm{i}}$ and IWQI, four irrigation water quality classes (I, II, III and IV) were created (Table 1). The classification was determined based on the range of values from -1.96 to 1.96 for class I. This indicates a $95 \%$ probability that the $\mathrm{WQI}_{\mathrm{i}}$ value is statistically equal to the reference population; in other words, the values of the indices contained in the determined interval do not present any degree of restriction. The other classes were obtained according to table 1.

Table 1. Condition for classification of the Water Quality Index for the characteristic evaluated $\left(W I_{i}\right)$ and for the Irrigation Water Quality Index (IWQI)

\begin{tabular}{ll}
\hline \multicolumn{1}{c}{ Classe } & \multicolumn{1}{c}{ Condition } \\
\hline I (Excellent) & $\mathrm{WQI}_{\mathrm{i}}$ or $\mathrm{IWQI} \leq 1.96$ \\
$\mathrm{II}$ (Good) & $1.96<\mathrm{WQI}_{\mathrm{i}}$ or $\mathrm{IWQI} \leq 5.88$ \\
III (Average) & $5.88<\mathrm{WQI}_{\mathrm{i}}$ or $\mathrm{IWQI} \leq 9.80$ \\
IV (Poor) & $\mathrm{WQI}_{\mathrm{i}}$ or $\mathrm{IWQI}>9.80$ \\
\hline
\end{tabular}

A linear model of the IWQI was adjusted as a function of EC. The equations adjusted for each characteristic evaluated per water source were compared by the model identity test to verify the null hypothesis that the equations are statistically equivalent (Regazzi, 1996). The model identity test was applied comparing each equation two by two, that is, applying the test for each IWQI two by two. Analyses were performed using software SAEG, developed by the Universidade Federal de Viçosa (Federal University of Viçosa), MG, Brazil. 


\section{RESULTS AND DISCUSSION}

The results of the mean values, standard deviations and coefficients of variation (CV) for the characteristics evaluated and for the different water sources in the reference samples are shown in table 2 . These values are standards to obtain the classification index of ionic composition, as well as the quality of the irrigation water.

The mean values and $\mathrm{CV}$ were highest for $\mathrm{HCO}_{3}+\mathrm{CO}_{3}$ and $\mathrm{SO}_{4}$, respectively, for the three water sources. The ions with lowest variability were $\mathrm{Ca}$ in the well and reservoir water, and $\mathrm{HCO}_{3}+\mathrm{CO}_{3}$ for river water. This variability per water source and per ion may partially explain the different regression equations per source where the weight of an ion in the sum of the square does not exclusively depend on its concentration but on its interaction with the others when ion effects on the EC of the water are evaluated (Maia et al., 2001). In relation to the predominance of $\mathrm{HCO}_{3}+\mathrm{CO}_{3}$, Maia \& Rodrigues (2010) observed that when the EC of waters reaches $0.6 \mathrm{dS} \mathrm{m}^{-1}, 0.52 \mathrm{dS} \mathrm{m}^{-1}$ and $0.43 \mathrm{dS} \mathrm{m}^{-1}$, the $\mathrm{HCO}_{3} / \mathrm{Cl}$ ratio is $<1$ for well, river and dam reservoir waters respectively, indicating that only from this EC level there is predominance of chloride over $\mathrm{HCO}_{3}$. Since EC was below $0.7 \mathrm{dS} \mathrm{m}^{-1}$ when defining the reference samples, this explains the predominance of $\mathrm{HCO}_{3}+\mathrm{CO}_{3}$ in these waters, regardless of the source.

For the IWQI of the 247 samples of well water, it was observed that $32(12.96 \%), 148(59.92 \%)$, $40(16.19 \%)$ and $27(10.93 \%)$ were classified as IWQI I, II, III and IV, respectively, i.e., showing predominance of good water quality. Moreover, it was observed that at a single source there are waters of different qualities; there must therefore be planning which allows the best use of these waters. Although the quality of most source waters is good, there are inferior waters which can however be used in irrigation, be it separately or mixed or alternated with good water quality. In such cases, the use of inferior water quality depends on the salinity tolerance of crops and on the irrigation management (Oliveira \& Maia, 1998).

Of all well samples, only was classified in I for all $\mathrm{WQI}_{\mathrm{i}}$. This would be water of excellent quality in view of the values of its indices. The other samples, despite classification I for IWQI, were classified differently for $\mathrm{WQI}_{\mathrm{i}}$.

Figure 1 shows the classification using $\mathrm{WQI}_{\mathrm{i}}$ and IWQI for sample $66\left(\mathrm{EC}=1.05 \mathrm{dS} \mathrm{m}^{-1}\right.$, and 2.60, 2.13, 7.34, 0.10, 3.09, 8.79 and $0.46 \mathrm{mmol}_{\mathrm{c}} \mathrm{L}^{-1}$ of Ca, $\mathrm{Mg}, \mathrm{Na}, \mathrm{K}, \mathrm{Cl}, \mathrm{HCO}_{3}+\mathrm{CO}_{3}$ and $\mathrm{SO}_{4}$, respectively), $140\left(\mathrm{EC}=1.30 \mathrm{dS} \mathrm{m}^{-1}\right.$, and 3.71, 4.48, 5.38, 0.15, 6.90, 5.24, and $1.28 \mathrm{mmol}_{\mathrm{c}} \mathrm{L}^{-1}$ of $\mathrm{Ca}, \mathrm{Mg}, \mathrm{Na}, \mathrm{K}, \mathrm{Cl}$, $\mathrm{HCO}_{3}+\mathrm{CO}_{3}$, and $\mathrm{SO}_{4}$, respectively) and $154(\mathrm{EC}=$ $1.40 \mathrm{dS} \mathrm{m}^{-1}$, and 0.77, 2.08, 12.46, 0.07, 8.46, 4.78, and $0.75 \mathrm{mmol}_{\mathrm{c}} \mathrm{L}^{-1}$ of $\mathrm{Ca}, \mathrm{Mg}, \mathrm{Na}, \mathrm{K}, \mathrm{Cl}, \mathrm{HCO}_{3}+\mathrm{CO}_{3}$, and $\mathrm{SO}_{4}$ respectively). For sample 66 , although the IWQI index was II (good water quality) and $\mathrm{WQI}_{\mathrm{i}}$ II, in most cases, for $\mathrm{HCO}_{3}+\mathrm{CO}_{3}$, the $\mathrm{WQI}_{\mathrm{HCO}_{3}}+\mathrm{CO}_{3}$ was III, leading to an increase in the soil $\mathrm{pH}$ and thus contributing to reduce the availability of some nutrients such as $\mathrm{P}, \mathrm{Fe}$ and $\mathrm{Zn}$, as well as the soil fertility. In this situation, where $\mathrm{WQI}_{\mathrm{SO}_{4}}$ is II, $\mathrm{Na}_{2} \mathrm{SO}_{4}$ formation might occur in an environment that has sodium carbonate and gypsum, which is very toxic to plants. In addition, at a higher $\mathrm{pH}$ $(>7.5)$, there may be precipitation of calcium and magnesium carbonates that obstruct the nozzles and cause incrustations in the piping. Sulfate

Table 2. Mean value, standard deviation (SD) and coefficient of variation (CV) in the reference population $\left(\mathrm{EC}<0.7 \mathrm{dS} \mathrm{m}^{-1}\right)$ for the chemical characteristics $\mathrm{EC}, \mathrm{Ca}, \mathrm{Mg}, \mathrm{Na}, \mathrm{K}, \mathrm{Cl}, \mathrm{HCO}_{3}+\mathrm{CO}_{3}, \mathrm{SO}_{4}$, and $\mathrm{SAR}$ in the reference samples for the water sources evaluated

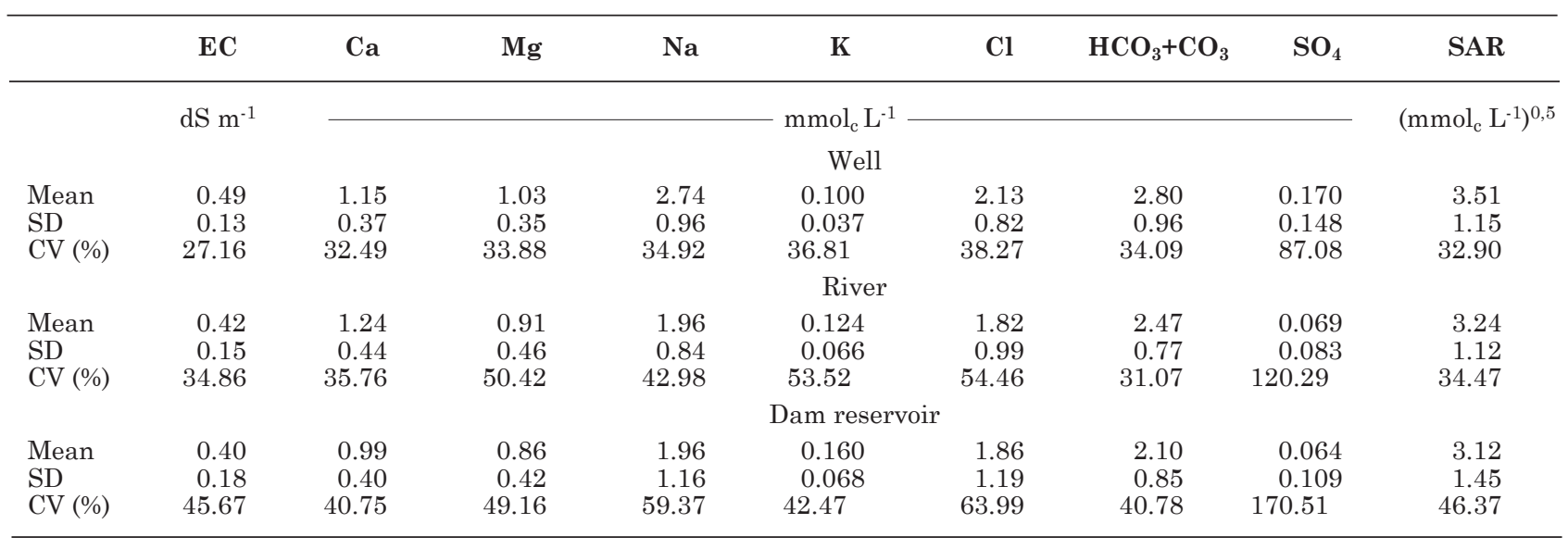


and chloride together are the main compounds responsible for soil salinization. High sulfate concentrations can promote $\mathrm{Na}$ uptake, decreasing Ca uptake, which interferes with $\mathrm{K}$ uptake, while high $\mathrm{Ca}$ concentration reduce $\mathrm{K}$ uptake.

Similar to sample 66 , the water quality of sample 140 was also considered good $(\mathrm{IWQI}=\mathrm{II})$, but its ionic composition by the $\mathrm{WQI}_{\mathrm{i}}$ indicated certain restrictions for $\mathrm{Ca}$ and $\mathrm{Mg}$, with $\mathrm{WQI}_{\mathrm{Ca}}$ and $\mathrm{WQI}_{\mathrm{Mg}}$ of III and IV respectively, and the concentrations of these elements in the sample 3.71 and $4.48 \mathrm{mmol}_{\mathrm{c}} \mathrm{L}^{-1}$ for $\mathrm{Ca}$ and $\mathrm{Mg}$, respectively. Comparing the $\mathrm{Ca}$ and $\mathrm{Mg}$ concentrations in the reference samples, it may be observed that the mean values are $1.15 \mathrm{mmol}_{\mathrm{c}} \mathrm{L}^{-1}$ for $\mathrm{Ca}$ and $1.03 \mathrm{mmol}_{\mathrm{c}} \mathrm{L}^{-1}$ for $\mathrm{Mg}$, far below the sample concentrations. Thus, this water must be used with caution for localized irrigation, in view of the risk of carbonate and
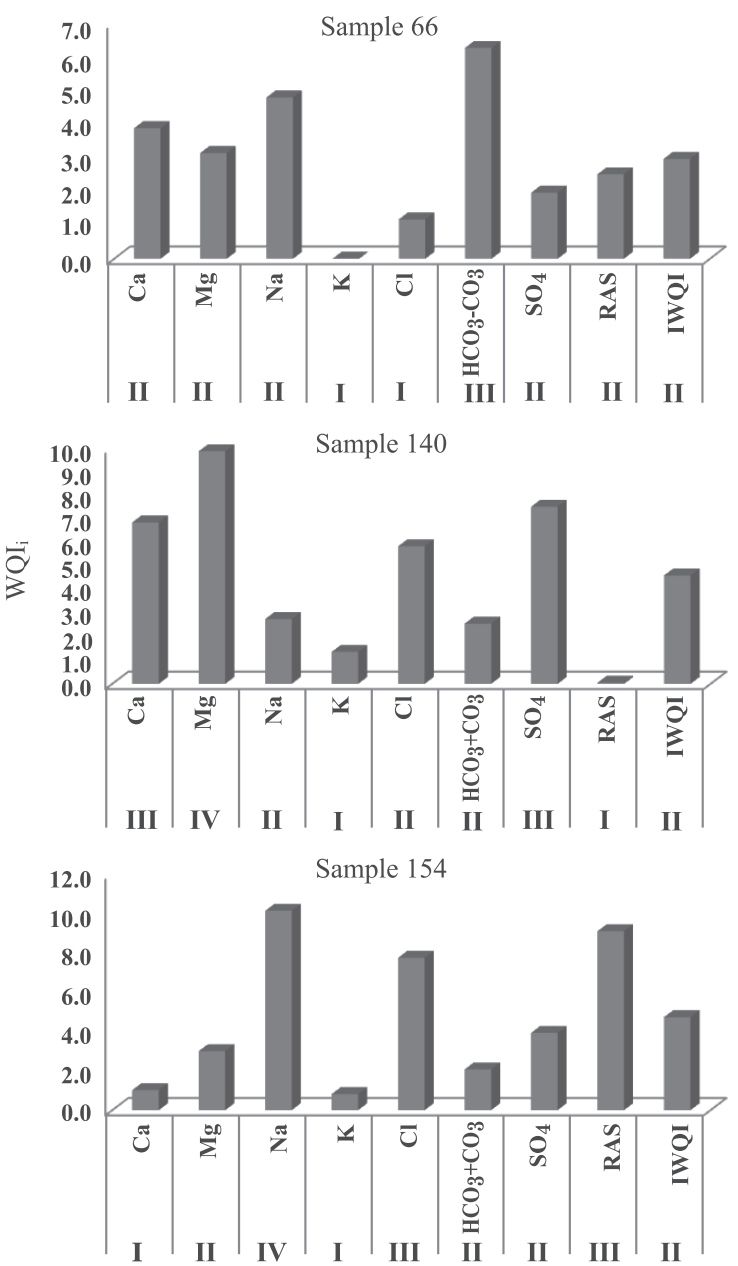

Figure 1. Classification of Quality Indices for chemical characteristics $\left(W Q I_{i}\right)$ and for irrigation water (IWQI) for samples 66 (EC of $\left.1.05 \mathrm{dS} \mathrm{m}^{-1}\right), 140$ (EC of $\left.1.30 \mathrm{dS} \mathrm{m}^{-1}\right)$ and $154(\mathrm{EC}$ of $1.40 \mathrm{dS} \mathrm{m}^{-1}$ ) of well water. phosphate precipitation. Limitations are required since the yields of some crops are reduced in soils with high $\mathrm{Mg}$ contents, or when irrigated with water with high $\mathrm{Mg}$ concentrations, even when infiltration is adequate (Ayers \& Westcot, 1991). This is due to the Ca deficiency induced by excess of soil exchangeable Mg (Maia, 1996). According to Boas et al. (1994), waters with high and severely hazardous levels of $\mathrm{Ca}$ and highly damaging levels of $\mathrm{Mg}$ may increase the precipitation of $\mathrm{P}$ in irrigation water; in addition, $\mathrm{Mg}$, after $\mathrm{Ca}$, is mainly responsible for water hardness. In contrast, waters with low EC (< $0.5 \mathrm{dS} \mathrm{m}^{-1}$ ) will only be satisfactory if the water has enough $\mathrm{Ca}$, because low $\mathrm{Ca}$ contents may increase infiltration problems in some soils.

Another example is observed in sample 154, in which, as for samples 66 and 140, the IWQI was II; however, for this sample, $\mathrm{WQI}_{\mathrm{Na}}, \mathrm{WQI}_{\mathrm{Cl}}$ and $\mathrm{WQI}_{\mathrm{SAR}}$ of IV, III and III were observed, respectively. In this case, the $\mathrm{Na}$ quantity in the water may be limiting for agricultural use. Na-saturated soil with a high SAR value may result in soil sodification. This is due to the valence and hydrated radius of this element; it is subject to dispersion, impeding water infiltration, reducing the wet profile of the soil, thus affecting nutrient uptake in the subsurface soil layers. In addition, high $\mathrm{Na}$ concentrations in the soil inhibit the uptake of other cations, especially $\mathrm{Ca}, \mathrm{Mg}$ and $\mathrm{K}$, which is intensified by waters with low concentrations of $\mathrm{Ca}$ and $\mathrm{Mg}$. High $\mathrm{Cl}$ contents interfere with the uptake of other anions, especially nitrate and sulfate, and toxicity is most often due to the presence of $\mathrm{Cl}$ in irrigation water. Mendlinger \& Pasternak (1992) evaluated the effect of salinity on yield and quality reduction of melon fruit and found that excess sodium and chloride lead to an ionic imbalance that affects the selectivity of the membranes of root cells. Therefore, high $\mathrm{Na}$ content displaces $\mathrm{Ca}$ from the root cell membranes, altering their integrity, thus affecting the selectivity of other nutrients, such as K.

The example of these three samples indicates that the IWQI is an average index for the characteristics evaluated in the irrigation water, thus the importance of evaluating water quality also by the WQI $I_{i}$. The reason is that, as the IWQI is estimated by the average $\mathrm{WQI}_{\mathrm{i}}$, in a same sample there may be very low $\mathrm{WQI}_{\mathrm{i}}$ values that reduce the IWQI values. This shows the importance of interpreting irrigation water quality for each determination.

For the chemical characteristics EC, $\mathrm{Ca}, \mathrm{Mg}, \mathrm{Na}$, $\mathrm{K}, \mathrm{Cl}, \mathrm{HCO}_{3}+\mathrm{CO}_{3}$, and $\mathrm{SO}_{4}$ in the river water, the IWQI values and the referent classifications of the indices in the 38 water samples were classified as follows: 1 sample with index I (2.63\%), 28 (73.68 \%) with index II, 6 (15.79\%) with index III and 3 
samples (7.89 \%) with index IV. For DAM reservoir water, of the 79 samples evaluated, 9 (11.39\%), 57 (72.15\%), $11(13.92 \%)$ and $2(2.53 \%)$ were IWQI I, II, III, and IV, respectively. Comparing the water sources, most samples were IWQI II, with 59.92, 73.68 and $72.15 \%$ for well, river and DAM reservoir water, respectively. Another observation is that only $2.63 \%$ of the river samples were classified as IWQI I and only $2.53 \%$ as IWQI IV, for dam reservoir water.

Similarly to the well waters, for some samples from the river and dam reservoir, aside from the IWQI classification, an analysis of the $\mathrm{WQI}_{\mathrm{i}}$ values complements the information on the quality of these waters for irrigation. For the river water samples 02 and 03 , in spite of having the same EC, the IWQI is 2.224 (II) and 1.926 (I), respectively (Table 3). This higher IWQI value of sample 02 is mainly due to the higher $\mathrm{SO}_{4}$ concentration, with $\mathrm{WQI}_{\mathrm{SO}_{4}} \mathrm{III}$, although EC is $0.75 \mathrm{dS} \mathrm{m}^{-1}$. For sample 33, although IWQI is III, care must be taken in relation to $\mathrm{Mg}, \mathrm{Na}, \mathrm{Cl}$, and $\mathrm{SO}_{4}$, which have a $\mathrm{WQI}_{\mathrm{i}}>9.8$, and index IV. For DAM reservoir water, although sample 42 was classified as IWQI II, care must be taken with $\mathrm{Mg}$ and $\mathrm{Cl}$, which had WQI $\mathrm{III}_{\mathrm{i}}$. Comparing samples 67 and 68 , although they have nearly the same EC, the greater Ca concentration in sample 68, resulted in classification IWQI III and IWQI II for sample 67 (Table 3).

Although most samples were classified as satisfactory by the IWQI, a detailed evaluation of the $\mathrm{WQI}_{\mathrm{i}}$ is important to know the water quality for irrigation for some samples, since some ions may have higher than reference values, although these values are diluted in the IWQI calculation. Therefore, even when IWQI is low and some WQI value is high, soil properties may be altered through the use of the water, as mentioned for well waters with high concentrations of $\mathrm{Ca}, \mathrm{Mg}, \mathrm{Na}$ and $\mathrm{SO}_{4}$.

IWQI can be estimated as a function of EC for the three water sources $\left(R^{2}>0.90\right)$ (Figure 2$)$; however,
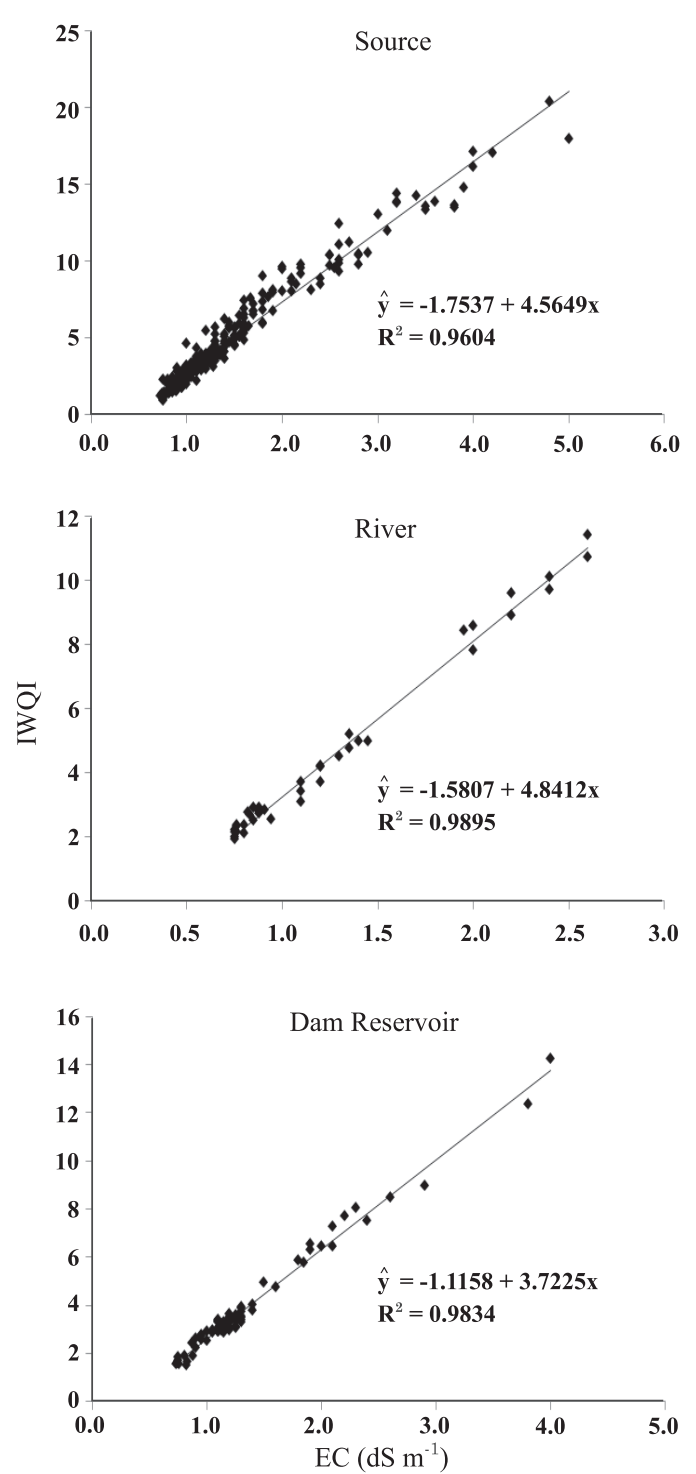

Figure 2. Irrigation Water Quality Index (IWQI) as a function of Electrical Conductivity (EC) for the three water sources (well, river, dam reservoir).

Table 3. Values of EC, WQI $\mathrm{I}_{\mathrm{i}}$ and IWQI for some river and dam reservoir water samples

\begin{tabular}{|c|c|c|c|c|c|c|c|c|c|}
\hline Sample & EC & $\mathbf{C a}$ & Mg & $\mathrm{Na}$ & $\mathbf{K}$ & Cl & $\mathrm{HCO}_{3}+\mathrm{CO}_{3}$ & $\mathrm{SO}_{4}$ & IWQI \\
\hline & $\mathrm{dS} \mathrm{m}^{-1}$ & \multicolumn{7}{|c|}{ - WQI $\mathrm{I}_{\mathrm{i}}$} & \\
\hline & \multicolumn{9}{|c|}{ River Water } \\
\hline 02 & 0.75 & 2.367 & 2.771 & 0.586 & 0.364 & 2.561 & 1.037 & 5.881 & II \\
\hline 03 & 0.75 & 3.179 & 2.488 & 0.158 & 0.063 & 2.853 & 0.060 & 4.683 & I \\
\hline 33 & 2.20 & 4.960 & 10.427 & 13.702 & 4.751 & 15.590 & 2.564 & 10.317 & III \\
\hline & \multicolumn{9}{|c|}{ Dam Reservoir Water } \\
\hline 42 & 1.20 & 3.111 & 6.005 & 3.859 & 0.290 & 6.246 & 0.250 & 5.659 & II \\
\hline 67 & 1.85 & 3.309 & 10.107 & 8.723 & 0.595 & 12.628 & 1.127 & 4.005 & II \\
\hline 68 & 1.90 & 7.167 & 12.465 & 7.655 & 1.038 & 15.295 & 0.230 & 1.985 & III \\
\hline
\end{tabular}


based on the model identity test, it is not possible to estimate the IWQI for the three water sources by a single equation. This confirms the hypothesis that for each time period and source, a single regression equation might not explain the variability of ion concentration in the water, as observed by Ribeiro et al. (2005). This was also suggested by Maia et al. (2001), who stated that when all water sources are considered in the classification, the waters together differed completely from the classification per source, showing that it is possible to classify waters statistically, however, for practical uses, the ideal procedure is to classify them by region and within this region, for a certain water source. Thus, based on EC, the IWQI may classify the waters as excellent, good, average and poor for IWQI I, II, III, and IV respectively, and this classification varied with the EC, according to the source evaluated (Table 4). However, a relationship was only observed between the $\mathrm{WQI}_{\mathrm{i}}$ values and $\mathrm{EC}$ for $\mathrm{Mg}$, $\mathrm{Na}$ and $\mathrm{Cl}$. The explanation for this is that $\mathrm{EC}$ is a measurement that quantitatively expresses the quantity of salts in the irrigation water, without specifying the types of salts. In this regard, based on EC, the IWQI of the water can be estimated and, only in some cases, related with the $\mathrm{WQI}_{\mathrm{i}}$.

\section{Table 4. Condition for classification of the Irrigation} Water Quality Index (IWQI) based on EC

\begin{tabular}{|c|c|}
\hline IWQI/Classification & Condition for EC $\left(\mathrm{dS} \mathrm{m}^{-1}\right)$ \\
\hline \multicolumn{2}{|c|}{ Well } \\
\hline I (Excellent) & $\mathrm{EC} \leq 0.81$ \\
\hline II (Good) & $0.81<\mathrm{EC} \leq 1.67$ \\
\hline III (Average) & $1.67<\mathrm{EC} \leq 2.53$ \\
\hline IV (Poor) & $\mathrm{EC}>2.53$ \\
\hline \multicolumn{2}{|c|}{ River } \\
\hline I (Excellent) & $\mathrm{EC} \leq 0.73$ \\
\hline II (Good) & $0.73<\mathrm{EC} \leq 1.54$ \\
\hline III (Average) & $1.54<\mathrm{EC} \leq 2.35$ \\
\hline IV (Poor) & $\mathrm{EC}>2.35$ \\
\hline \multicolumn{2}{|c|}{ Dam Reservoir } \\
\hline I (Excellent) & $\mathrm{EC} \leq 0.83$ \\
\hline II (Good) & $0.83<\mathrm{EC} \leq 1.88$ \\
\hline III (Average) & $1.88<\mathrm{EC} \leq 2.93$ \\
\hline IV (Poor) & $\mathrm{EC}>2.93$ \\
\hline
\end{tabular}

It is important to emphasize that this water classification method can be used for other ions, such as nitrate and phosphate, provided that the reference samples, in addition to the mean value of these ions, also contain the variability measured by the standard deviation. The values for classification would those in table 1 .

\section{CONCLUSIONS}

1. The method proposed for the Irrigation Water Quality Index allowed a satisfactory classification of the irrigation water quality, by estimating it as a function of $\mathrm{EC}$ for the three water sources.

2. Variation was observed in the ionic composition of the three water sources and within a single water source. Although different water qualities were observed, water with good quality was predominant, classified as IWQI II.

\section{LITERATURE CITED}

AUDRY, P. \& SUASSUNA, J.A. Salinidade das águas disponíveis para a pequena irrigação, no sertão nordestino. Recife, Fundação Joaquim Nabuco/CNPq, 1995. 128p.

AYERS, R.S. \& WESTCOT, D.W. A qualidade da água na agricultura. Campina Grande, Universidade Federal da Paraíba, 1991. 218p. (FAO. Estudos de Irrigação e Drenagem, 29)

BOAS, R.L.V.; BOARETTO, A.E. \& VITTI, G.C. Aspectos da fertirrigação. In: VITTI, G.C. \& BOARETTO, A.E., eds. Fertilizantes fluidos. Piracicaba, Potafos, 1994. 343p.

GANFOPADHYAY, S.; GUPTA, A. \& NACHABE, M.H. Evaluation of ground water monitoring network by principal component analysis. Ground Water, 39:181-191, 2001.

MAIA, C.E.; MORAIS, E.R.C. \& OLIVEIRA, M. Classificação da composição iônica da água de irrigação usando regressão linear múltipla. R. Bras. Eng. Agric. Amb., 5:55-59, 2001.

MAIA, C.E. Qualidade da água para fertirrigação nas regiões da chapada do Apodi e baixo Açu-RN.-Mossoró, ESAM, 1996. 122p. (Monografia de Especialização)

MAIA, C.E. \& RODRIGUES, K.K.R.P. Relação entre bicarbonato e cloreto em águas para fins de irrigação. In: WORKSHOP INTERNACIONAL DE INOVAÇÕ̃ES TECNOLÓGICAS NA IRRIGAÇÃO, 4., Fortaleza, 2010. Anais... Fortaleza, 2010. CD ROM.

MEDEIROS, J.F. Qualidade de água de irrigação e evolução da salinidade nas propriedades assistidas pelo "Gat" nos estados do RN, PB e CE. Campina Grande, Universidade Federal de Campina Grande, 1992. 173p. (Tese de Mestrado)

MENDLINGER, S. \& PASTERNAK, D. Screening for salt tolerance in melons. HortScience, 27:905-907, 1992.

OLIVEIRA, M. \& MAIA, C.E. Qualidade físico-química da água para a irrigação em diferentes aquíferos na área sedimentar do Estado do Rio Grande do Norte. R. Bras. Eng. Agric. Amb., 2:17-21, 1998. 
REGAZZI, A.J. Teste para verificar a identidade de modelos de regressão. Pesq. Agropec. Bras., 31:1-17, 1996.

RIBEIRO, G.M.; MAIA, C.E. \& MEDEIROS, J.F. Uso da regressão linear para estimativa da relação entre a condutividade elétrica e a composição iônica da água de irrigação. R. Bras. Eng. Agric. Amb., 9:15-22, 2005.

SHALHEVET, J. \& KAMBUROV, J. Irrigation and salinity: A world-wide survey. New Delhi, Caxton Press, 1976. 106p.
SINGH, K.P.; MALIK, A. \& SINHA, S. Water quality assessment and apportionment of pollution sources of Gomti river (India) using multivariate statistical techniques-A case study. Anal. Chim. Acta, 538:355-374, 2005.

STIGTER, T.Y.; RIBEIRO, L. \& DILL, A.M.M.C. Application of a groundwater quality index as an assessment and communication tool in agro-environmental policies - Two Portuguese case studies. J. Hydrol., 327:578-591, 2006. 